\title{
МОДЕРНІЗАЦІЯ ПІСЛЯДИПЛОМНОЇ ПЕДАГОГІЧНОЇ ОСВІТИ: СУЧАСНИЙ ПОГЛЯД ТА ПРІОРИТЕТИ
}

Сергеєва Л. М. Модернізація післядипломної педагогічної освіти: сучасний погляд та пріоритети.

У статті розглядаються питання оновлення форм організації післядипломної педагогічної освіти для забезпечення конкурентоздатності педагогічних $\mathrm{i}$ науковопедагогічних працівників, розкриваються традиційні підходи до впровадження нових моделей розвитку післядипломної педагогічної освіти.

Ключові слова: конкурентоздатність, педагогічні і науково-педагогічні працівники, менеджмент знань, колаборативна форма навчання.

Сергеева Л. Н. Модернизация последипломного педагогического образования: современный взгляд и приоритеты.

В статье рассматриваются вопросы обновления форм организации последипломного педагогического образования для обеспечения конкурентоспособности педагогических и научно-педагогических работников, раскрываются нетрадиционные подходы к внедрению новых моделей последипломного педагогического образования.

Ключевые слова: конкурентоспособность, педагогические и научно-педагогические работники, менеджмент знаний, колоборативная форма обучения.

Serheieva L. N. Modernization of postgraduate education: contemporary outlook and priorities.

The article deals with establishing new forms of organizing postgraduate pedagogical education for ensuring the competitive advantage of pedagogical and scientific-pedagogical staff. Innovative approaches to the implementation of new forms of postgraduate pedagogical education are revealed.

Key words: competitive ability, pedagogical and scientific-pedagogical staff, management of knowledge, collaborative form of education.

Характер сучасного людського розвитку зумовлює зростання потреби в найвищих дослідницьких кваліфікаціях, з-поміж яких - післядипломна педагогічна освіта (далі - ППО) педагогічних і науково-педагогічних працівників (далі- П/НПП). Ефективність діяльності сучасного фахівця в ринкових умовах значною мірою залежить від сформованості його особистісних характеристик, що визначають потенційні можливості в досягненні успіху, адекватну поведінку в мінливих умовах сьогодення, забезпечують упевненість у собі, гармонію 3 собою і навколишнім світом, іншими словами, його конкурентоздатність. Важливого значення набуває ця проблема для П/НПП, що за своїм призначенням мають підготувати прийдешні покоління до професійної діяльності в ринкових умовах.

Основними тенденціями світової професійної освіти XXI століття є іiї глобалізація, величезна конкуренція серед фахівців, технологічна та інформаційна революція, глобалізація інформаційного обміну, швидке старіння отриманих знань. В умовах ринкової економіки, інформаційно-технологічного розвитку розширюються функції ППО, відбувається іiі трансформація у постдокторську освіту, що відповідає світовим тенденціям неперервної 
освіти - освіти впродовж життя.

Теоретичний аналіз наукової літератури (Г. Балл, Т. Бабенко, В. Бикова, О. Бондарчук, Л. Галаган, С. Гончаренко, І. Зязюн, М. Євтух, Л. Карамушка, В. Кремінь, Т. Кутейніцина, А. Лавринчук, В. Луговий, П. Лушин, С. Максименко, Н. Ничкало, В. Олійник, А. Печенюк, В. Рибалка, Л. Сергеєва, С. Сисоєва, О. Слюсаренко, Ж. Таланова, Л. Хомич, Є. Чернишова та ін.) та аналіз практики діяльності фахівців свідчить про певний «дисонанс» між високими вимогами ринку та недостатнім рівнем реальної конкурентоздатності його суб'єктів.

Водночас, аналіз практики діяльності П/НПП свідчить також і про недостатній рівень їхньої конкурентоздатності, а потенціал системи ППО, здатної забезпечити відповідну психолого-педагогічну підготовку, реалізується недостатньо повно. Метою статmі є пошук нових моделей розвитку ППО, нових форм організації та нетрадиційних підходів до їх упровадження.

Постійне вдосконалення ППО, системи підготовки, перепідготовки та підвищення кваліфікації П/НПП зумовлене зміною ролі людини в сучасному світі, баченням ідеалу освіченості людини та висуванням нових вимог до якості людського капіталу відповідно до культурно-духовних, суспільно-економічних i технологічних трансформацій, а також чисельних викликів глобального, європейського, національного, регіонального та місцевого рівнів. Адже самі П/НПП мусять бути зразком конкурентоздатної особистості, яку вони прагнуть виховати в кожного суб'єкта освіти.

Проблему поглиблює реальне розмаїття формалізації згаданої підготовки. Ïї актуалізація обгрунтовується певними чинниками, серед яких: дослідницько-інформаційним типом прогресу; прискоренням зміни соціально-культурного світу; загостренням конкурентної змагальності; необхідністю особистісного зростання. Основою розвитку П/НПП є нові знання, які набуваються у процесі професійного навчання осіб та /або підвищення кваліфікації.

Сучасний цивілізаційний поступ базується на застосуванні концепції менеджменту знань, що визначається як рушійна сила соціальних технологій, що формують створення нових інституцій, які кардинально змінюють та вносять структурні технологічні зміни до системиосвіти та визначає такі основні їі функції: генерування знань (індивідуальним або організаційним навчанням); формалізація знань (розроблення принципів, правил і процедур); збереження знань (визначення певного типу носіїв для збереження, що допускають розподіл знань); дифузія знань (розподіл знань у межах організації та в обмеженому варіанті поза нею); координація та контроль знань (забезпечення того, щоб знання були точними i постійними); формування знань (виявлення інформаційних джерел, отримання інформації від них, вивчення, структурування і трансформацію інформації у знання та подальше їх відтворення); розроблення загальної стратегії бізнесу; розповсюдження передового досвіду; навчання персоналу; отримання знань про клієнтів; управління інтелектуальними ресурсами, інновації; захист знань; оновлення та розвиток знань, інтеграція накопичених і нових знань.

Менеджмент знань - це сучасна концепція розвитку організації, що базується на цілеспрямованій діяльності людей, яка забезпечує процес генерування, накопичення, зберігання і використання знань у колективах організацій [7, с. 33]. Педагоги та науковці мають забезпечити взаємини суспільства, природи, культури та освіти в умовах глобалізації, інтернаціоналізації та формування суспільства «економіки знань», тобто нового типу економічної організації суспільства, у якому вирішальна роль належить сектору знань, а виробництво знань $є$ джерелом зростання економіки.

Тенденції глобалізаційних процесів перебувають у тісному взаємозв'язку із 
становленням постіндустріального суспільства, е якому вирішальну роль відіграє розвиток не просто сектора освітніх послуг, а в першу чергу секторів, пов'язаних із усеосяжною інформатизацією суспільства та продукуванням знань (економіки, що грунтується на знаннях).

Ще у 2006 р. британська організація «The Work Foundation» у рамках програми 3 вивчення терміна «економіка знань» (knowledge economy) підготувала звіт, у якому зазначалося, що термін «економіка знань» походить від повного визнання місця знань $\mathrm{i}$ технологій у сучасних економічних системах країн Організації економічного співробітництва і розвитку (ОЕСР), підкреслюючи, що економіки цих країн все більше і більше грунтуються на знаннях та інформації. Знання вважають чинником підвищення продуктивності та економічного зростання [2, с. 49].

Розглядаючи педагогічну і наукову діяльність у зв'язку з ії продуктами - науковими знаннями, зазначимо, що освіта і наука залучається до суспільного життя в інформаційному суспільстві та вимагає трансформації принципів організації наукової діяльності. Різке зростання наукових досліджень можна спробувати пояснити 3 найзагальніших позицій, а саме, з позицій загальносвітової тенденції зближення науки і практики. Це зумовлює зміни і в ППО через глобалізацію, яка передбачає послаблення й подальше усунення економічних, культурних та інших кордонів між країнами, збільшення міграційних потоків у сферах економіки, зайнятості, освіті; інтернаціоналізацію, яка відображає посилення міжнародного виміру в освітній, науковій, інноваційній діяльності освітніх закладів; формування економіки знань як перехід від індустріальної економіки до економіки, основним ресурсом у якій $є$ знання.

Важливим ресурсом поповнення та збагачення знань, використання їх при формуванні сучасної інституційної інноваційної інфраструктури є система ППО, для вдосконалення та розвитку якої розробляються і впроваджуються відповідні механізми. Головною метою їх упровадження, спрямованою на вдосконалення системи освіти, $\epsilon$ створення умов для приведення рівня і якості освітнього потенціалу та кадрового забезпечення країни відповідно до вимог ринкової економіки.

Основними пріоритетами розв'язання цього завдання є прискорена модернізація вітчизняної системи підготовки конкурентоздатного П/НПП в умовах ППО з урахуванням передових здобутків людства; осучаснення змісту, методів i форм підготовки конкурентоздатного фахівця за єдиним критерієм - глобальна конкурентоспроможність та створення умов якісної підготовки впродовж життя на основі компетентнісного підходу як основи людиноцентризму. В. Кремінь наголошує, що «конкурентоздатний науковопедагогічний працівник має бути глобалістською людиною інноваційного типу і водночас патріотом України» [4, с. 2].

В основу розробленої Галузевої концепції розвитку неперервної педагогічної освіти (2013) покладено прогностичні ідеї, а в їх змістах ураховано стан і прогнози розвитку економіки, ринку праці України, а також об'єктивні потреби оновлення змісту і форм організації підвищення конкурентоздатності вітчизняних П/НПП. Концептуальними для післядипломної освіти вважаються ідеї стійкого руху до європейського освітнього простору, забезпечення нової якості освіти та професійного розвитку, перетворення навчання протягом життя на реальність, створення системи методичного супроводу управління на основі інноваційних стратегій тощо. Модернізація ППО сьогодні пов'язується саме із запровадженням різних видів мережевих систем, які дають змогу об'єднувати інформаційні ресурси, створювати освітній простір, що сприяє розвитку конкурентоздатності П/НПП. Їхня 
підготовка та професійне вдосконалення - важлива умова модернізації освіти в цілому.

Державна політика в галузі підготовки П/НПП спрямована на вдосконалення професійного відбору та підготовки молоді, створення необхідних умов для свідомого обрання педагогічного фаху та запровадження системи професійного відбору молоді до вищих педагогічних навчальних закладів. Держава забезпечує умови для піднесення престижу і соціального статусу П/НПП, їхнього професійного і культурного зростання. При цьому слід визнати, що престиж «ученості» і науковців 3 одного боку, знижується, а 3 іншого - поєднується зі зростаючим прагненням значної кількості людей отримати наукові дипломи високого рангу, що, природно, призводить до їх девальвації.

Слід визнати, що навіть найкращі вищі навчальні заклади не можуть стовідсотково забезпечити високоякісну підготовку фахівців «на всі часи», тому все більш помітне місце в рамках вищої школи займає післядипломна освіта - організоване й систематично здійснюване навчання дипломованих працівників з метою «осучаснення» їхніх професійних знань. Розвиток післядипломної освіти - важливий аспект реформування вищої школи, який має значний вплив на їі організацію і діяльність.

Формами ППО доцільно вважати науково-практичні семінари-практикуми, всеукраїнські та міжнародні науково-практичні конференції, участь у міжнародних інноваційних педагогічних проектах, авторські наукові школи, наукові та педагогічні читання, розробка навчального курсу, наукове редагування рукопису, творча відпустка, закордонне стажування тощо.

Формою підготовки науковців $\epsilon$ наукові школи, які можуть бути розглянуті як елемент системи післядипломної педагогічної освіти, що забезпечують можливість багатовимірного руху особистості в освітньому просторі та соціалізацію дослідниківпочатківців у науковій спільноті. Особливості наукових шкіл як педагогічних систем забезпечують індивідуалізацію навчання, де для кожного вибудовується «власна» траєкторія руху в освітньому просторі школи відповідно до його інтересів і можливостей [1, с. 63].

Оновленню моделі підвищення кваліфікації значною мірою сприяє інтеграція професійної освіти і вимог ринку праці та ринку освітніх послуг. Навчальний процес у закладах ППО грунтується на принципах професійно-творчого розвитку і саморозвитку педагога, де провідна роль відведена самостійності слухачів та їхній досвід. Однією 3 результативних форм навчання $є$ колаборативна форма (навчання у співпраці) - це спільне розслідування, у результаті якого слухачі працюють разом, колективно конструюючи, продукуючи нові знання - інноваційну форму взаємодії в навчальному процесі.

Ця педагогічна технологія вважається однією з найбільш трудомістких і не завжди надає очікуваний результат. Проте дослідження свідчать, що за умови використання колаборативної форми навчання засвоюється значно більше матеріалу і його засвоєння $є$ міцнішим. Це підхід, у рамках якого навчання побудоване на тісній взаємодії між слухачами, між слухачами та викладачем. Перенесення центру уваги на слухачів зменшує можливості викладачів демонструвати свої знання та досвід і надає ці можливості педагогам, що підвищують свою психолого-педагогічну кваліфікацію. Взаємини між учасниками колаборативної групи детермінуються такими характеристиками, як: демократичність, рівноправність, автономність.

Під час занять домінують моделювання професійних ситуацій та спільне розв’язання поставлених навчально-практичних проблем. Така форма навчання сприяє організації групи слухачів та спрямовує їх на прийняття рішень за рахунок реалізації потенційних можливостей групи загалом і кожного їі учасника окремо [3, с. 66]. 
Академік В. Олійник справедливо зауважує, що необхідно посилити практичну спрямованість занять, яку довести до 70\%. При цьому важливим має стати використання засвоєного досвіду на практиці для розв'язання конкретних проблем, широке застосування завдань аналітичного характеру, розв'язування нестандартних, ситуативних завдань [5, c. 56].

Найкращим результатом діяльності фахівця в умовах конкуренції $\epsilon$ його конкурентоздатність. Людина, яка прагне гідного соціального статусу та позиції у суспільстві і бажає бути конкурентоспроможною на ринку праці, мусить неперервно навчатися нового, засвоювати як нові знання, так і набувати нових умінь i навичок. Дослідження стверджують, що однією із професійно важливих якостей сучасного фахівця $€$ конкурентоздатність як свідчення його високого рівня підготовленості до професійної діяльності та здатності до постійного й неперервного навчання й самонавчання.

Отже, сучасні умови жорсткої конкуренції на ринку праці висувають нові вимоги і до П/НПП. В умовах значних організаційно-економічних змін у сфері наукової та інноваційної діяльності відбувається трансформація основних завдань, що покладаються на П/НПП: це не лише виконання освітньої функції, а й можливість здійснювати наукові дослідження з метою випуску інноваційної, наукоємної продукції з ії подальшим упровадженням у виробництво.

Визнано, що конкурентоспроможність навчальних закладів на ринку освітніх послуг безпосередньо залежить від рівня кваліфікації П/НПП, їх наукового рівня та педагогічної майстерності. У зв'язку з цим, в основу концепції дослідження покладено філософські ідеї гуманітарної парадигми: суб’єкт освітнього професійного вдосконалення - вільна і духовно розвинена людина, яка має потребу в особистісному зростанні, професійному розвитку та саморозвитку і самовдосконаленні після здобуття освіти. Її складники передбачають теоретико-методологічні (мета, завдання, принципи, підходи), процесуальні (педагогічні умови, компоненти, критерії та чинники) та технологічні (шляхи, форми і методи) основи.

Подальші наукові розвідки доцільно спрямувати на розв'язання проблеми щодо модернізації змісту психолого-педагогічної підготовки фахівців в умовах ППО задля забезпечення формування та розвитку їхньої конкурентоздатності.

\section{Література}

1. Грезнева О. Ю. Научные школы как одна из форм непрерывного образования и социализации начинающих исследователей / О. Ю. Грезнева // Материалы докладов и сообщений участников второй международной конференции [«Образование через всю жизнь: проблемы становления и развития непрерывного образования »], (г. Санкт-Петербург, 4-5 июня 2002 г.) / под науч. ред. Н. А. Лобанова и В. Н. Скворцова. - Санкт-Петербург : Файндер, 2003. - С. 63-66. 2. Іванова В. В. Економіка, заснована на знаннях, та економіка знань: адекватність використання категорій / Валентина Іванова // Механізм регулювання економіки. - 2011. - № 3. - С. 47-54. 3. Кожушко С. Стратегія колаборативного навчання у вищому навчальному закладі /Світлана Кожушко // Молодь і ринок. - 2014. - № 5 (112). С. 65-70. 4. Кремень В. Г. Усвідомлюючи відповідальність за розвиток людини, консолідацію нації та європейської інтеграції України. Доповідь президента НАПН України на Загальних зборах академії «Про діяльність НАПН України у 2014 р. та завдання на 2015 р.» / В. Г. Кремень / Педагогічна газета. - 2015. - № 2 (246). - С. 2. 5. Олійник В. В. Тенденції розвитку післядипломної педагогічної освіти в умовах трансформації суспільства / В. В. Олійник // Теорія і практика управління соціальними системами. - 2013. - № 1. - С. 5666. б. Полянська А. С. Менеджмент знань у вітчизняній практиці / А. С. Полянська // Технологический аудит и резервы производства. - 2013. - № 6 / 6 (14). - С. 32-34. 